\title{
Analysis of mortality from suicide in children, adolescents and youth. Argentina, 2005-2007
}

\author{
Mónica E. Bella, ${ }^{a, b}$ M.D., Laura Acosta ${ }^{a}$, B.S., Belén Villacéa , B.S., \\ María López de Neira ${ }^{a}, M g .$, Julio Enders ${ }^{a}$, M.D., and Ruth Fernández $z^{a}$, M.D.
}

\begin{abstract}
Objective. To analyze mortality from suicide in children, adolescents and youth aged 5 to 24 years by gender, method used, place where the incident occurred and residence (province) in Argentina over the period 2005-2007.

Method. Data of Statistical Death Reports were used. Mortality rates from suicide were estimated per 100000 inhabitants using ICD-10 (X60X84). The statistical method included categorical data analysis.

Results: Total deaths from suicide in the 5 to 24 year old group were 861 in 2005, 897 in 2006, and 815 in 2007. During the period 2005-2007, 6 deaths occurred in children younger than 10 years old. In the 10 to 24 year old group males had higher rates than females $(\mathrm{p}<0.01)$. Analysis by gender and age group showed an increase of suicide in males in the group aged 20-24 years old $(p<0.01)$, while females had the highest rates of suicide in the 15 to 19 year old group. Hanging and use of firearms were the most frequent methods ( $\mathrm{p}<0.01)$. The home was the most frequent place where the incident occurred $(p<$ 0.01 ). Santa Cruz, Salta and Jujuy had the highest rates of suicide in Argentina, whereas Santiago del Estero, Capital Federal and Misiones showed the lowest ones.

Conclusion. Suicide in Argentinean adolescents and youth is a public health problem, especially among males. The provinces in the North and South of Argentina had the highest rates in the country.

Key words: mortality, suicide, adolescent, youth, Argentina.
\end{abstract}

http:/ /dx.doi.org/10.5546/aap.2013.16

a. Public Health School. School of Medical Sciences. Universidad Nacional de Córdoba.

b. Hospital de Niños de la Santísima Trinidad. Córdoba, Argentina.

E-mail:

Mónica E. Bella, M.D.: bellamonica@ hotmail. com

Conflict of interest: None.

Received: 02-10-2012 Accepted: 08-03-2012

\section{INTRODUCTION}

Mortality from violent causes in adolescents and youth (10-24 years old, according to the World Health Organization [WHO]) is one of the most significant health problems and, in the Americas, it constitutes the main cause of death in this age group. ${ }^{1-6}$ Accidents, suicides and homicides are listed as the leading causes of violent deaths.

Suicide is a complex public health issue, and its causes are related to biological, psychological and social factors; it affects the younger population and it leads to emotional and economic losses.
WHO estimates indicate that currently one million people from all age groups commit suicide around the world, and this estimate may go up to 1.5 million people by $2020,5,7,8$ Suicide deaths, as every death from violent causes, may be prevented as long as information on factors leading to suicide is available and prevention programs and timely treatments are developed.

In Argentina, mortality from suicide in adolescents and youth increased from 1.5 per 100000 inhabitants in 1990 to 10.7 per 100000 inhabitants in 2007, and the 20-25 year old age group underwent the highest increase. ${ }^{2,4,8-10}$ Most studies on this issue focus on the older than 10 year old group, and there are a few references about what happens in children younger than 10 years old.

Based on the above mentioned, the aim of this article was to analyze mortality from suicide in children, adolescents and youth aged 5 to 24 years old per gender, method used, place where the incident occurred and jurisdiction of the place of residence (province) in Argentina, for the 2005-2007 period.

\section{MATERIAL AND METHODS}

Observational and descriptive study of suicide deaths recorded in 5 to 24 year old male and female children, adolescents and youth in Argentina for the 2005-2007 period.

Data were obtained from death databases provided by the Statistics and Health Information Department of the Ministry of Health of Argentina. Data were analyzed by age group, gender, method of suicide used, place where the incident occurred and jurisdiction.

Causes of death were classified as per the International Classification 
of Diseases and Related Health Problems, $10^{\text {th }}$ Revision (ICD-10), chapter on External causes of morbidity and mortality, which covers intentional self-harm (suicides) and includes codes $\mathrm{X} 60$ to $\mathrm{X} 84 .{ }^{11}$ For analysis purposes, intentional self-harm is grouped as follows: poisoning (X60$X 69)$, hanging (X70), firearm discharge (X72$X 74)$, jumping from a high place (X80), suicide by unspecified means (X84), and others (X71; X75-X79; X81-X82). ${ }^{11}$

For suicide analysis by age, age groups were divided in 5-year intervals and defined according to the development stages of childhood, adolescence and youth. Four stages were characterized: childhood, from 5 to 9 years old; early adolescence, from 10 to 14 years old; middle adolescence, from 15 to 19 years old, and late adolescence or youth, from 20 to 24 years old. ${ }^{6}$ All records with complete age and gender data were included in the statistical analysis.

Data for 5 to 24 year old children, adolescents and youth were analyzed through the 2005-2007 three-year period frequency by suicide method and place where the incident occurred according to gender and age group. Absolute and relative frequencies were estimated and reported in percentages. A low frequency was found in the 5 to 9 year old group; therefore, its results are stated only in a descriptive manner. For the 10 to 24 year old group, the specific suicide mortality rates per 100 000 inhabitants were estimated among adolescents and youth for the 2005-2007 three-year period at a national level and at residence jurisdiction level. The numerator was the average of deaths between 2005 and 2007, and the denominator was the population estimated by the Population Statistics Department of the National Statistics and Censuses Institute of Argentina (Instituto Nacional de Estadísticas y Censos de la Argentina, INDEC) for 2006.

The statistical analysis was performed by means of categorized data; the significance level used was 0.05 .

\section{RESULTS}

\section{Analysis of suicide rate per gender and age group}

The absolute total number of suicide deaths in the 5 to 24 year old group was 861 in 2005, 897 in 2006, and 815 in 2007, with the highest values in males ( $p<0.001$ ) (Table 1). In the 5 to 9 year old group, a total of 6 deaths occurred in the 20052007 period, 3 males in 2005, 2 females in 2006, and 1 male in 2007.
Table 2 shows the rate of suicide deaths per age group and gender. The analysis of suicide death rate in adolescents and youth per age group and gender showed that, in males, the risk increases with age $(p<0.01)$, while the group with the highest risk in females is that of 15 to 19 years old ( $p$ $<0.05$ ) (Table 2).

\section{Analysis of suicide methods per age group and gender}

In children aged 5 to 9 years old, the suicide methods chosen were hanging in three, firearm discharge in two, and other methods in one.

In the 10 to 24 year old group, the most commonly used suicide methods were hanging in $65.3 \%$ and $67.9 \%$ of males and females, respectively; and firearm discharge in $29.5 \%$ and $13.0 \%$ of males and females, respectively.

Table 3 shows the rate of suicides for the 20052007 period in children, adolescents and youth per self-harm method according to their age group and gender, being hanging and firearm discharge the most commonly chosen methods by males $(\mathrm{p}<0.01)$.

TABle 1. Distribution of suicide deaths in the 5 to 24 year old group per gender and year in Argentina in the 2005-2007 period

\begin{tabular}{lcccc}
\hline & \multicolumn{4}{c}{ Gender } \\
Year & n & \% & n & \% \\
\hline 2005 & 169 & 19.6 & 692 & 80.4 \\
2006 & 202 & 22.5 & 695 & 77.5 \\
2007 & 183 & 22.5 & 632 & 77.5 \\
\hline
\end{tabular}

Source: Based on data provided by the Statistics and Health Information Department of the Ministry of Health of Argentina.

Abbreviations. $\mathrm{F}=$ female; $\mathrm{M}=$ male.

TABLE 2. Distribution of suicide deaths in the 5 to 24 year old group per age group and gender in Argentina in the 2005-2007 period

\begin{tabular}{lcccc}
\hline & \multicolumn{4}{c}{ Gender } \\
Age group & $\mathbf{~}$ & $\mathbf{\%}$ & $\mathbf{n}$ & $\mathbf{M}$ \\
\hline $5-9$ & 2 & 0.4 & 4 & 0.2 \\
$10-14$ & 79 & 14.3 & 135 & 6.7 \\
$15-19$ & 276 & 49.7 & 841 & 41.7 \\
$20-24$ & 197 & 35.6 & 1039 & 51.4 \\
Total & 554 & 100 & 2019 & 100 \\
\hline
\end{tabular}

Source: Based on data provided by the Statistics and Health Information Department of the Ministry of Health of Argentina.

Abbreviations. $\mathrm{F}=$ female; $\mathrm{M}=$ male. 


\section{Analysis of suicide per place where the incident occurred and age group}

The analysis of suicides per place where the incident occurred disclosed 1 death in a public health facility in the 5 to 9 year old group, 3 at home, and no indication of the place in 2 cases (Table 4). In the 10 to 24 year old group, the most common place where the suicide occurred was at home or private address followed by other place, and public health facilities in the third place. A comparative analysis of studied age groups showed that the 10 to 14 year old group had a higher rate of death at home or private address than the 15 to 19 year old group $(\mathrm{p}<0.01)$ and the 20 to 24 year old group $(\mathrm{p}<0.01)$. Table 4 shows the results of the analysis of suicides per place where the incident occurred and age group.

\section{Suicide rate analysis per jurisdiction in Argentina}

The analysis of suicide deaths per jurisdiction found that, in the 5 to 9 year old group, 3 deaths occurred in Buenos Aires, 1 in Córdoba, 1 in Salta and 1 in Tierra del Fuego.

Suicide rate analysis per jurisdiction in the 10 to 24 year old group showed a mean rate of 8.49 deaths per 100000 inhabitants in the 2005-2007 three-year period for Argentina. The following jurisdictions had higher rates than the rest of the country: Santa Cruz (18.97), Salta (18.10), Jujuy (17.53), Tucumán (16.95), Chubut (15.70), Neuquén (14.51), Catamarca (11.56), Formosa (10.82), Entre Ríos (10.65), Tierra del Fuego (10.43), Río Negro (10.38), and Chaco (8.79); while Santiago del Estero (3.94), Capital Federal (5.26), Misiones (5.73), San Luis (6.54), San Juan (6.93), La Pampa (7.07), Santa Fe (7.21), Córdoba (7.42), Corrientes (7.54), Buenos Aires (7.54), Mendoza (7.77), and La Rioja (8.23) had lower rates.

The suicide mortality rate in Santa Cruz was 2.23 times higher than the country rate, while it was 2.15 times lower in Santiago del Estero. The jurisdictions in the North and South of Argentina had higher suicide rates (Figure 1).

\section{DISCUSSION}

In Argentina, suicide among adolescents and youth constitutes a health issue that continues to grow, and a change in the epidemiological profile of suicides in Argentina has been found in studies conducted over the last decades. While suicide rates in groups older than 25 years old have sta-

TABLE 3. Distribution of suicide deaths per self-harm method according to gender and age group in Argentina in the 20052007 period

\begin{tabular}{|c|c|c|c|c|c|c|c|c|c|c|}
\hline \multirow{3}{*}{$\begin{array}{l}\text { Self-harm method used } \\
\text { Age } \\
\text { Gender }\end{array}$} & \multicolumn{10}{|c|}{ Absolute rate } \\
\hline & \multicolumn{2}{|c|}{$5-9$} & \multicolumn{2}{|c|}{ 10-14 } & \multicolumn{2}{|c|}{ 15-19 } & \multicolumn{2}{|c|}{$20-24$} & \multicolumn{2}{|c|}{$5-24$} \\
\hline & $\mathbf{F}$ & $\mathbf{M}$ & $\mathbf{F}$ & $\mathbf{M}$ & $\mathbf{F}$ & $\mathbf{M}$ & $\mathbf{F}$ & $\mathbf{M}$ & $\mathbf{F}$ & $\mathbf{M}$ \\
\hline Poisoning & 0 & 0 & 2 & 3 & 11 & 9 & 8 & 7 & 21 & 19 \\
\hline Hanging & 2 & 1 & 60 & 101 & 187 & 539 & 128 & 676 & 377 & 1317 \\
\hline Firearm discharge & 0 & 2 & 7 & 30 & 38 & 257 & 27 & 307 & 72 & 596 \\
\hline Jumping from a high place & 0 & 0 & 7 & 1 & 24 & 8 & 21 & 8 & 52 & 17 \\
\hline Others & 0 & 1 & 1 & 0 & 6 & 19 & 3 & 21 & 10 & 41 \\
\hline Unspecified & 0 & 0 & 2 & 0 & 10 & 9 & 10 & 20 & 22 & 29 \\
\hline Total & 2 & 4 & 79 & 135 & 276 & 841 & 197 & 1039 & 554 & 2019 \\
\hline
\end{tabular}

Source: Based on data provided by the Statistics and Health Information Department of the Ministry of Health of Argentina. Abbreviations: $\mathrm{F}=$ female; $\mathrm{M}=$ male.

TABLE 4. Distribution of suicide per place where the incident occurred and age group in Argentina in the 2005-2007 period

\begin{tabular}{|c|c|c|c|c|c|c|c|c|c|c|}
\hline \multirow[b]{3}{*}{ Place of incident } & \multicolumn{10}{|c|}{ Age group } \\
\hline & \multicolumn{2}{|c|}{$5-9$} & \multicolumn{2}{|c|}{$10-14$} & \multicolumn{2}{|c|}{ 15-19 } & \multicolumn{2}{|c|}{$20-24$} & \multicolumn{2}{|c|}{$5-24$} \\
\hline & $\mathbf{n}$ & $\%$ & $\mathbf{n}$ & $\%$ & n & $\%$ & $\mathbf{n}$ & $\%$ & $\mathbf{n}$ & $\%$ \\
\hline Public health facility & 1 & 16.7 & 25 & 11.7 & 113 & 10.1 & 107 & 8.7 & 246 & 9.5 \\
\hline Private health facility, health insurance facility & 0 & 0.0 & 0 & 0.0 & 10 & 0.9 & 17 & 1.4 & 27 & 1.0 \\
\hline Home or private address & 3 & 50.0 & 140 & 65.4 & 605 & 54.2 & 675 & 54.6 & 1423 & 55.3 \\
\hline Other place & 0 & 0.0 & 27 & 12.6 & 222 & 19.9 & 260 & 21.0 & 509 & 19.8 \\
\hline Unspecified & 2 & 33.3 & 22 & 10.3 & 167 & 14.9 & 177 & 14.3 & 368 & 14.3 \\
\hline Total & 6 & 100 & 214 & 100 & 1117 & 100 & 1236 & 100 & 2573 & 100 \\
\hline
\end{tabular}

Source: Based on data provided by the Statistics and Health Information Department of the Ministry of Health of Argentina. 
bilized, the 10 to 24 year old group shows an upward trend..$^{8-10,12,13}$

The suicide rate analysis per gender showed a higher effect on males, and this trend is consistent with the information provided by other authors, both for Argentina and other countries. $2,8,9,12,14-20$ This feature is explained by the high fatality rate of the methods chosen to commit suicide, usually hanging and firearms, and the neurological and psychopathological characteristics of each gender. Pathologies related to impulsivity, such as behavioral disorders and substance use, among others, are more common in males. ${ }^{20-27}$

FIGURE 1. Distribution of suicide mortality rates per 100 000 inhabitants in adolescents and youth aged 10 to 24 years per jurisdiction of Argentina in the 2005-2007 threeyear period

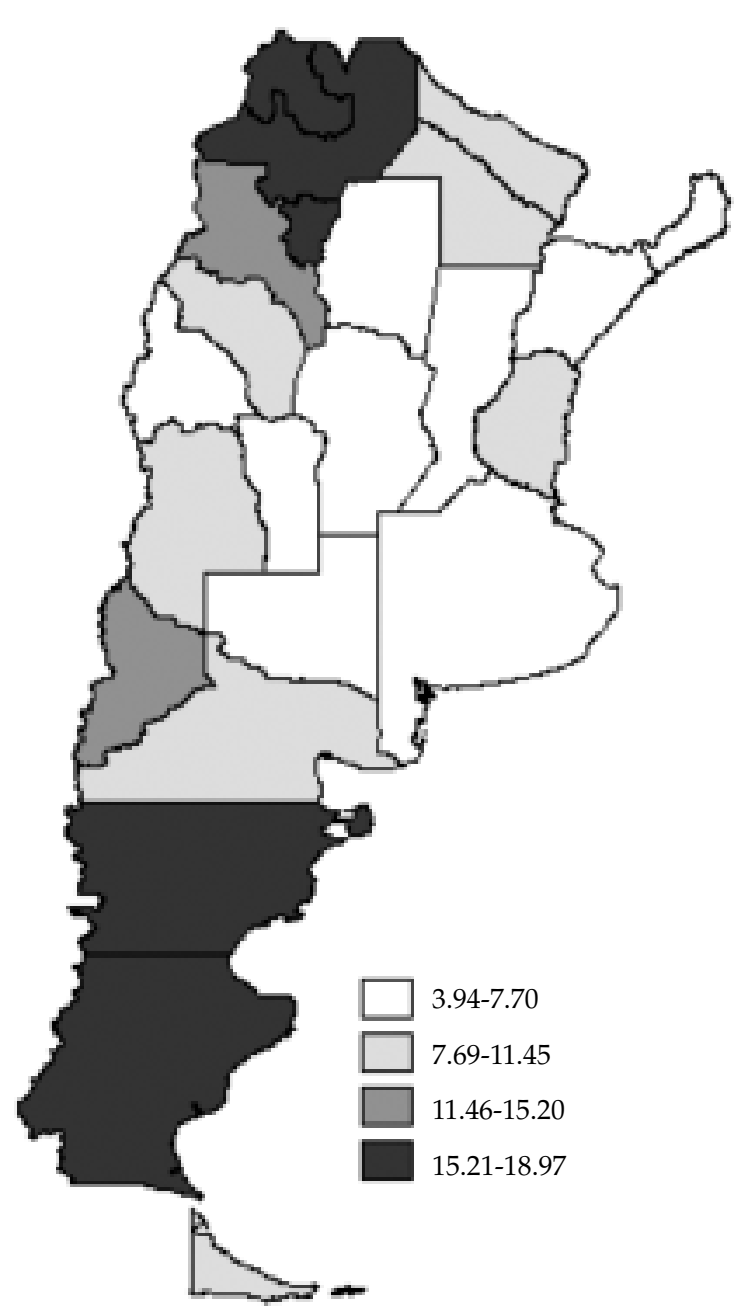

Source: Based on data provided by the Statistics and Health Information Department of the Ministry of Health of Argentina.
The analysis of the method most frequently used to commit suicide in Argentina revealed that it continues to be hanging, and this differs from what has been observed in other countries, such as Colombia and USA, where firearms is the most commonly used method. ${ }^{1,15,16,28}$ This feature is related to Argentina's cultural patterns, given that civilians have an easier access to the elements required for hanging, which are everyday objects and easy to acquire. Another aspect that should be taken into consideration is the use of firearms as a suicide method.

The analysis of suicide rates per jurisdiction showed that the most affected regions were the North (Jujuy and Salta) and the South (Chubut, Río Negro, Neuquén and Santa Cruz) of Argentina, with figures twice as high as the mean rate for Argentina. This geographic trend had already been seen in a prior study for the 1990-2000 period for the southern jurisdictions. ${ }^{2}$ It should be noted, however, that a change has been observed in Chubut: while the rates are higher than the mean for the rest of the country, in this province the trend is downward. In 2000, this jurisdiction had a suicide rate of 18.14 deaths every 100000 inhabitants in the 10 to 24 year old group (making it the jurisdiction with the highest suicide rate in Argentina), while the rate was 15.70 every 100000 inhabitants for the 2005-2007 three-year period. ${ }^{2}$

However, Santiago del Estero has a suicide rate lower than the mean rate for Argentina, and this aspect should be studied more thoroughly because there might be different factors influencing such situation. One of the factors that is worth mentioning, and that should be examined in greater detail, is the difficulty of finding reliable suicide mortality records. There is evidence of omission in child mortality for the Santiago del Estero jurisdiction; the studies conducted suggest that "the magnitude of such omission is very important and negatively affects the validity of child mortality indicators." 29,30

The study is limited, since Argentina's registry system allows to identify social and demographic aspects involved in suicide deaths, but does not allow to identify the basic causes of the serie of events leading to a premature death. In this regard, records of this type of deaths in children, adolescents and youth should be complemented with psychological autopsies, an expert technique contributing to recreate the individual's life so as to identify factors involved in such decision, including, among others, mental condition, personality, triggering stressful events, and commu- 
nication of suicidal ideas. These aspects would allow to better recognize factors related to this type of deaths and develop health measures for a more timely intervention, linking epidemiological aspects with the clinical, cultural and social and economic characteristics of Argentina.

In addition, for this article we found suicide deaths in children aged 5 to 9 years old, and this aspect should be reviewed in greater depth in different studies so as to identify the variables involved in the desire to die in such early stages of life.

Population studies on suicide attempt relate suicidal behaviors in children with serious dysfunctional family situations, psychopathological disorders, and the use of high fatality methods, as those detected in this study: hanging and firearm discharge. ${ }^{31,32}$

\section{CONCLUSION}

Suicide in adolescents and youth of Argentina constitutes an ever growing health issue and evidences a gender-differentiated behavior, with a higher effect in males. The most commonly used suicide method was hanging, and the northern and southern jurisdictions presented the highest suicide rates.

\section{BIBLIOGRAPHY}

1. Yunes J, Zubarew T. Mortalidad por causas violentas en adolescentes y jóvenes un desafío para la región de las Américas. Rev Bras Epidemiol 1999;2(3):102-71.

2. Serfaty E, Foglia L, Masautis A, Negri G. Mortalidad por causas violentas en adolescentes y jóvenes de 10 a 24 años. Vértex 2007;(40):25-30.

3. Duarte C, Bordín I, De Paula C, Hoven C. Conductas suicidas en adolescentes brasileños: análisis exploratorio de prevalencia y factores de riesgo. Rev Psiquiatr Salud Int 2002;2(4):32-7.

4. Vuegen S. Salud de la población adolescente en la Argentina. Arch Argent Pediatr 2003;101(6):491-4.

5. Organización Mundial dela Salud. Elsuicidio, un problema de salud pública enorme y sin embargo prevenible. (Press release). [Accessed on:22.06.11]. Available at: http:/ / www. who.int/mediacentre/new/ releases/2004/pr61/es/.

6. Organización Mundial de la Salud. La salud de los jóvenes. Informe de un grupo de estudio de la OMS acerca de los jóvenes y de la salud para todos en el año 2000. Serie de informes técnicos 731. Ginebra 1986. [Accessed on: 22.06.11]. Available at: http://whqlibdoc.who.int/ trs/WHO-TRS731-spa.

7. Concha-Eastman A, Krug E. Informe mundial sobrela salud y la violencia. Rev Panam Salud Pública 2002;12(4): 227-9.

8. Serfaty E, Andrade JH, Foglia L, Masautis A, Negri G. Suicidio en adolescentes y jóvenes de 10-24 años. Argentina 1991-2000. Rev Sinopsis 2006;22(42):17-21.

9. Sola M. Sociodemografía del suicidio en la población adolescente y joven en Argentina, 1999-2007. Rev Argent Salud Pública 2011;2(9):18-23.
10. Ministerio de Salud de la Nación. Dirección de Estadísticas e Información en Salud. Serie 5 Estadísticas Vitales. Información Básica. Año 2000-2007. [Accessed on: March 1, 2012]. Available at: http:/ / www.deis.gov.ar.

11. Organización Mundial de la Salud. Clasificación Internacional delas Enfermedades. Décima Edición. Ginebra;1992.

12. Zeballos JL. Argentina. efectos socio-sanitarios de la crisis, 2001-2003. Buenos Aires: Organización Panamericana de la Salud, 2003 (Publicación Científica No 57).

13. Dirección de Promoción de la Salud y Control de Enfer medades No Transmisibles. Perfil epidemiológico del suicidio en la Argentina 1988-2008. Boletín de vigilancia de enfermedades no trasmisibles y factores de riesgo $\mathrm{N}^{\circ} 2$ : (5):58-78.

14. Basile H. El suicidio adolescente en la Argentina. ALCMEON. Rev Argent Clín Neuropsiq 2005; 12(3):211-31.

15. Cardona D, Peláez E, Aidar T, Ribotta B, Álvarez MF. Mortalidad por causas externas en tres ciudades latinoamericanas: Córdoba (Argentina), Campinas (Brasil) y Medellín (Colombia), 1980-2005. Rev Bras Est Pop São Paul 2008;25(2):335-52.

16. Cendales R, Vanegas C, Fierro M, Córdoba R, Olarte A. Tendencias del suicidio en Colombia. 1985-2002. Rev Panam Salud Pública 2007;22(4):

17. Levi F, La Vecchia C, Lucchini F, Negri E, et al. Trends in mortality from suicide, 1965-99. Acta Psichiatr Scand 2003;108(5):341-9.

18. Llorca Castro F, Ortún Rubio V. Mortalidad innecesariamente prematura y sanitariamente evitable en Costa Rica. Rev Panam Salud Pública 2010;84(6):

19. Borges G, Orozco R, Benjet C, Medina-Mora M. Suicidio y conductas suicidas en México: retrospectiva y situación actual. Salud Pública Mex 2010;52(4):292-304.

20. Puentes-Rosas E, López-Nieto L, Martínez-Monroy T. La mortalidad por suicidios: México 1990-2001. Rev Panam Salud Pública 2004;16(2):102-9.

21. Bella ME, Fernández RA, Willington JM. Intento de suicidio en niños y adolescentes: depresión y trastorno de conducta disocial como patologías más frecuentes. Arch Argent Pediatr 2010;108(2):124-9.

22. Shaffer D, Gould M, Fisher P, Trautman P, et al. Psychiatry diagnosis in child and adolescent suicide. Arch Gen Psychiatr 1996;(53):339-48.

23. Heuveline P, Slap GB. Adolescent and young adult mortality by cause. Age gender and country 1955 to 1994 . J Adolescent Health 2002;30(1):29-34.

24. Ocampo R, Bojorquez I, Cortés M. Consumo de sustancias y suicidios en México: resultados del Sistema de Vigilancia Epidemiológica de las Adicciones, 1994-2006. Salud Pública Mex 2009;51(4):306-13.

25. Espinoza-Gómez F,Zepeda-Pamplona V, Bautista Hernández V, Hernández-Suarez CM, et al. Violencia doméstica y riesgo de conducta suicida en universitarios adolescentes. Salud Pública Mex 2010;52(3):213-19.

26. Wasserman D, ChengQ, JiangGX.Global suiciderates among young people aged. World Psychiatry 2005;4(2): 114-20.

27. Gould MS, Greenberg T, Velting D, Shaffer D. Youth suicide risk and preventive interventions: a review of the past 10 years. J Am Acad Child Adolesc Psychiatry 2003;42(4): 386405.

28. Dervic K, Brent D, Orquendo M. Completed suicide in childhood. Psychiatr Clin North Am 2008;31(2):271-91.

29. Dirección de Estadísticas e Información en Salud. Estadísticas Vitales - Información Básica Año 2004 (Anuario). Buenos Aires: Dirección de Estadística e Información en Salud del Ministerio de Salud y Ambiente de la Nación; 2005.

30. Fernández M, Gevel C, Krupizki H, Marconi E, Casas C. Omisión de registro de nacimientos y muertes infantiles: 
magnitud, desigualdades y causas. Buenos Aires: Organización Panamericana de la Salud - Ministerio de Salud; 2008.

31. Bella ME, Fernández RA, Willington JM. Identificación de factores de riesgo en intentos de suicidio infantojuveniles. III Rev Argent Salud Pública 2010;1(3):24-29.

32. Pandolfo A, Vazques M, Mas M, Vomero A, et al. Intentos de autoeliminación en menores de 15 años. Experiencia en unServicio de Urgencias. Arch Argent Pediatr 2011;109(1):1823. 